\title{
A new report of Metacleobis fulvipes (Rower) (Solifugae, Mummuciidae) in central Brazil
}

\author{
Rodrigues, JCA. ${ }^{\mathrm{a} *}$, Pires-Júnior, OR. ${ }^{\mathrm{b}}$, Morales, $R A V^{\mathrm{b}}{ }^{\mathrm{b}}$ and Motta, $P C .^{\mathrm{a}}$ \\ áLaboratório de aracnídeos, Departamento de Zoologia, Instituto de Ciências Biológicas - IB, \\ Universidade de Brasília - UnB, Campus Darcy Ribeiro, Asa norte, CEP 70910-900, Brasília, DF, Brazil \\ bLaboratório de Toxinologia, Departamento de Ciências Fisiológicas, Instituto de Ciências Biológicas, \\ Universidade de Brasília - UnB, CEP 70910-900, Brasília, DF, Brazil \\ Received February 26, 2007 - Accepted March 21, 2007 - Distributed November 30, 2007 \\ *e-mail: janabiologa@gmail.com
}

The geographic distribution, systematics and general biology of the South American Solifugae are poorly known (Rocha and Cancello, 2002). Knowledge of the order in the Neotropical region is scarce especially in Brazil, which includes distinctive environments such as Caatinga and Cerrado that occupy a large portion of this country (Xavier and Rocha, 2001). In the last five years only 3 studies have been carried out focusing on Solpugida in Brazil: Xavier and Rocha (2001) described Mummucia mauryi as the first Solifugae from the Caatinga; Martins et al. (2004) reported the occurrence of $M$. coaraciandu in three cerrado phytophysiognomies; and Rocha and Cancello (2002) recently redescribed Metacleobis fulvipes (Rower, 1934) and reported new records for this species: in the Serra da Mesa (Goiás State) and in the Chapada dos Guimarães (Mato Grosso State), both in the Central Brazil cerrado. According to Rocha and Cancello (2002) this species exhibited a diurnal activity, walking and burrowing, and during the night remains inactive under pieces of wood. This study reports a new occurrence of Metacleobis fulvipes in the cerrado of Central Brazil, which amplifies the distribution of this species and also reinforces the necessity for more studies of arachnofauna in the cerrado. During the period of August and September/2004, in a region of Brasilia called São Sebastião, seven live specimens of M. fulvipes were collected using pitfall traps. Ten grids were set in three lines of six pitfalls traps. Each was put in three different cerrado phytophysiognomies: "cerradão", "cerrado Sensu strictu" and "campo sujo". Only in the grids localized in the "campo sujo" the presence of $M$. fulvipes were observed (GRID 1, $15^{\circ} 57^{\prime} 57.7^{\prime}$ ' S and $47^{\circ}$ 49' 41.4" W, Altitude $1133 \mathrm{~m}$; GRID 2, $15^{\circ} 58^{\prime}$ 09.8' S, 47 49' 43.6" W Altitude $1137 \mathrm{~m}$ ). The animals were fixed in ethanol $80 \%$ and deposited in the Laboratório de Aracnídeos at Brasilia University and in the Museum de Zoologia at São Paulo University. The specimens were identified by Dr. Ricardo Pinto-daRocha and are characterized by a brown chelicerae and three longitudinal pale brown stripes on the ectal face joined dorsally above the fondal teeth (Rocha and Cancello, 2002). The area of São Sebastião, a cerrado area which has been rapidly transformed into residential areas, is a grassland landscape characterized by an open area with sandy soil, Vellozia flavicans (Velloziaceae) and termites. The specimens were found only at this time in the area, and no other was found in any locality of Brasilia, but some more collections are necessary.

Acknowledgments - The authors would like to thank Dr. Ricardo Pinto-da-Rocha from São Paulo University for specimen identification.

\section{References}

MARTINS, EG., V. BONATO, G. MACHADO, R. PINTO-DAROCHA and ROCHA, LS., 2004. Description and ecology of a new species of sun spider (Arachnida: Solifugae) from Brazilian Cerrado. J. Nat.Hist., vol. 38, no. 18, p. 2361-2375.

MAURY, EA., 1984. Las familias de solifugos americanos y su distribucion geografica (Arachnida, Solifugae). Physis, C, vol. 42 , no. 103 , p. $73-80$.

ROCHA, LS. and CANCELLO, EM., 2002. Redescription of Metacleobis fulvipes Roewer from Brazil (Solifugae, Mummucidae). J. Arachnol, vol. 30, no. 1, p. 104-109.

XAVIER, E. and ROCHA, LS., 2001. Autoecology and description of Mummucia maury (Solifugae, Mummucidae), a new Solifugae from Brazilian semi-arid caatinga. J. Arachnol, vol. 29 , no. 2, p. 127-134. 